\title{
Mesothelin versus Ca-125 in Screening the Ovarian Malignancy
}

\author{
Mesothelin dan Ca-125 dalam Memprediksi Keganasan Ovarium
}

\author{
Meliana Jayasaputra, Freddy W Wagey, Max R Rarung \\ Department of Obstetrics and Gynecology \\ Faculty of Medical University of Sam Ratulangi/ \\ Prof. Dr. R. D. Kandou Hospital \\ Manado
}

\begin{abstract}
Objective: To determine the sensitivity and specificity of mesothelin compared with Ca-125 as a tumor marker in predicting ovarian malignancy.

Method: The cross sectional study design with diagnostic tests was conducted in 30 samples of patients undergoing elective laparotomy due to ovarian tumor. We compared the sensitivity and specificity between mesothelin and Ca-125, then the data were analyzed using SPSS software version 22.0.

Result: According to the ROC curve analysis, optimal sensitivity and specificity value of mesothelin was $63.2 \%$ and $54.5 \%$ at a cut-off point of $0.45 \mathrm{pg} / \mathrm{ml}$; or $42.1 \%$ and $72.7 \%$ at a cut-off point of 0.55 $\mathrm{pg} / \mathrm{ml}$. While the value of both optimal sensitivity and specificity of Ca- 125 was $73.7 \%$ and $63.6 \%$ at a cut-off point of $46.63 \mathrm{U} / \mathrm{ml}$.

Conclusion: Mesothelin and Ca-125 are not different significantly for the AUC value of $50 \%$. Due to higher sensitivity and specificity of Ca-125 than mesothelin, Ca-125 is still used as tumor marker for screening the ovarian malignancy.

[Indones J Obstet Gynecol 2016; 4-2: 107-110]

Keywords: Ca-125, mesothelin, ovarian malignancy
\end{abstract}

\begin{abstract}
Abstrak
Tujuan: Untuk menentukan sensitivitas dan spesifisitas mesothelin dibandingkan dengan antigen Ca-125 sebagai penana tumor dalam memprediksi keganasan ovarium.

Metode: Studi potong lintang dengan uji diagnostic dilakukan pada 30 pasien yang akan menjalankan laparotomy elektif karena tumor ovarium. Kami akan membandingkan sensitivitas dan spesifisitas antara mesotelin dan Ca-125. Data yang diperoleh kemudian dianalisis dengan menggunakan SPSS versi 22.0 dan dilakukan pembahasan sesuai literatur yang ada.

Hasil: Berdasarkan analisis kurva ROC, sensitivitas dan spesifisitas yang optimal pada mesothelin adalah $63,2 \%$ dan $54,5 \%$ dengan nilai cut-off $0,45 \mathrm{pg} / \mathrm{ml}$ dan $42,1 \%$ dan $72,7 \%$ dengan nilai cut off 0,55 $\mathrm{pg} / \mathrm{ml}$. Sedangkan, nilai sensitivitas optimal dan spesifisitas Ca-125 adalah 73,7\% dan 63,3\% dengan nilai cut-off 46,6 U/ml.

Kesimpulan: Mesotelin dan Ca-125 tidak berbeda bermakna pada nilai kurva AUC 50\%. Ca-125 memberikan nilai sensitivitas dan spesifisitas lebih tinggi dari mesotelin sehingga Ca-125 masih digu-nakan sebagai alat skrining keganasan ovarium.

[Maj Obstet Ginekol Indones 2016; 4-2: 107-110]

Kata kunci: Ca-125, keganasan ovarium, mesotelin
\end{abstract}

Correspondence: Meliana Jayasaputra. Department of Obstetrics and Gynecology. Prof. Dr. R. D. Kandou Hospital. Jln. Raya Tanawangko, Manado, North Sulawesi, 95115. Telephone: (0431) 959178, 859177. Email: meli.pochi@gmail.com

\section{INTRODUCTION}

Ovarian carcinoma as a malignant tumor in women after cervical and endometrial carcinoma has the prevalence rate of $2.4-5.6 \%$. This carcinoma causes mortality higher than other malignant tumors. It is because $70 \%$ of the cases is diagnosed in advanced stage (between stage III and IV) so that it has spread far beyond the ovary. Therefore, there is a need to find a highly effective screening tools in ovarian malignant tumor to reduce the morbidity and mortality of this disease. ${ }^{1,2}$ Excellent screening tools has high both sensitivity and specificity. ${ }^{1}$ One of the antigens released from the malignancy of the epithelial ovarian cells is Ca-125. ${ }^{1}$

Approximately, $83 \%$ of patients with ovarian malignant tumor had a high level of Ca-125, which showing the value more than $35 \mathrm{U} / \mathrm{ml}^{1,3}$ A study conducted in Sweden stated that the specificity of Ca-125 in ovarian malignant tumor was $97 \%$ and the positive predictive value (PPV) was $4.6 \%$. The low level of PPV was caused by the elevation of Ca-125 happened in several condition such as other malignant tumors like breast, pancreas, bladder, lung and liver cancer; as well as in other benign abnormalities including endometriosis, myoma uteri, tuba-ovarian abscess, benign ovarian cyst, ectopic pregnancy, diverticulitis; even in physiological conditions for example pregnancy and menstruation. Meanwhile, other tumor markers that could be detected in ovarian malignancies including Ca-19-9, Ca 15-3, Ca 72-4, LSA (lipid-associated sialic acid), LPA (lysophosphatide acid), osteopontin, and mesothelin. ${ }^{2,3}$ 
Mesothelin as a 40-kDa glycoprotein is bound to glucosilphosphatydillinositol. In normal tissues, the expression of mesothelin can be found on the mesothelial cells (cells that border the pleura, peritoneum and pericardium) and also epithelial cells of the trachea, tonsils, fallopian tubes, and kidneys. ${ }^{4}$ According to study by Hough, et al. in 2000, mesothelin was also expressed in ovarian carcinoma. Thus, it usually used as a screening tool in ovarian carcinoma. ${ }^{5}$ Lowe, et al. in their study stated that increased levels of mesothelin were higher in patients who had undergone optimal debulking compared with those with advanced ovarian cancer.6,7 In addition, $42 \%$ of patients who were at an early-stage of ovarian cancer also had elevated levels of mesothelin in the urine compared with only $12 \%$ of patients who had elevated in mesothelin serum. This proved that mesothelin had the potency as a screening tool to detect the ovarian carcinoma. ${ }^{8}$

Based on recent literatures, we would like to determine the relationship between mesothelin and Ca-125 as screening tools for ovarian malignant tumor.

\section{METHODS}

This cross sectional study to determine the diagnostic test was carried out in ovarian carcinoma patients who were registered at the gynecology out patient polyclinic in Prof. Dr. R. D. Kandou hospital. The inclusion criterias were the patients diagnosed as ovarian tumor, they would undergo the elective laparotomy, also they did not suffer from other malignancies. If they would like to participate, they had to sign the informed consent form. We excluded the patients who could not do the laparatomy. Besides, the result of biospy showed the tumor not original from the ovary was excluded. The patients were checked the blood samples to show the level of mesothelin. This examination was sent to Prodia laboratory, Manado. This study was conducted from June to August 2015.

By calculating using the formula, we had to fullfill minimally 30 samples of ovarian carcinoma. Data were analyzed by the ROC to calculate sensitivity and specificity levels of mesothelin to the histopathology samples of ovarian carcinoma. The data were processed using the software program of Statistical Product and Service Solutions (SPSS) for Windows version 22.0.

\section{RESULTS}

Of 30 patients included in this study, most of them $(18 / 50)$ were $40-59$ years old and more than half of patients $(18 / 30)$ were multi parity (Table 1 ). The histopathology characteristic of ovarian tumors showed that 2 samples were serous cystadenoma and 10 samples were mucinous cystadenoma as the benign ovary tumors. Meanwhile, ovarian serous cystadenocarcinoma was on 3 patients and the remaining was mucinous cystadenocarcinoma (15 samples) as malignant ovary tumors. This examination was done at the Laboratory of Pathology Anatomy Faculty of Medicine Universitas Sam Ratulangi, Manado.

Table 1. Characteristics of Respondents

\begin{tabular}{ccc}
\hline \hline Characteristics & & N (30) \\
\hline Age & $<20$ & 1 \\
& $20-39$ & 5 \\
& $40-59$ & 18 \\
& $\geq 60$ & 6 \\
Parity & 0 & 3 \\
& $1-2$ & 9 \\
& $3-5$ & 16 \\
& $>5$ & 2 \\
BMI & $\leq 18$ & 3 \\
& $18-24$ & 14 \\
& $\geq 25$ & 13 \\
\hline \hline
\end{tabular}

Based on the statistical group, Ca-125 levels had an average value of $412.0 \mathrm{U} / \mathrm{dl}$ with a standard deviation of 963.9. On the other hand, mesothelin levels showed an average value of $1.5 \mathrm{pg} / \mathrm{ml}$ with a standard deviation of 3.7 (figure 1). There was not correlation between mesothelin and ovarian malignant tumor $(\mathrm{p}=0.15 ; \mathrm{r}=0.15)$.

From the ROC method above, we obtained $59.8 \%$ (95\% CI $39.3-80.3 \%$ ) for AUC values of mesothelin. It meant that mesothelin levels were not significantly different to the $50 \%$ value of AUC. While, the AUC values of Ca-125 was $60.5 \%$ (95\% CI 38.3-80.3\%) which meant that Ca-125 levels were not significantly different from AUC value of $50 \%$.

From the table of coordinates, sensitivity and specificity for mesothelin levels with a "cut off point" of $0.45 \mathrm{pg} / \mathrm{ml}$ were $63.2 \%$ and $54.5 \%$; 


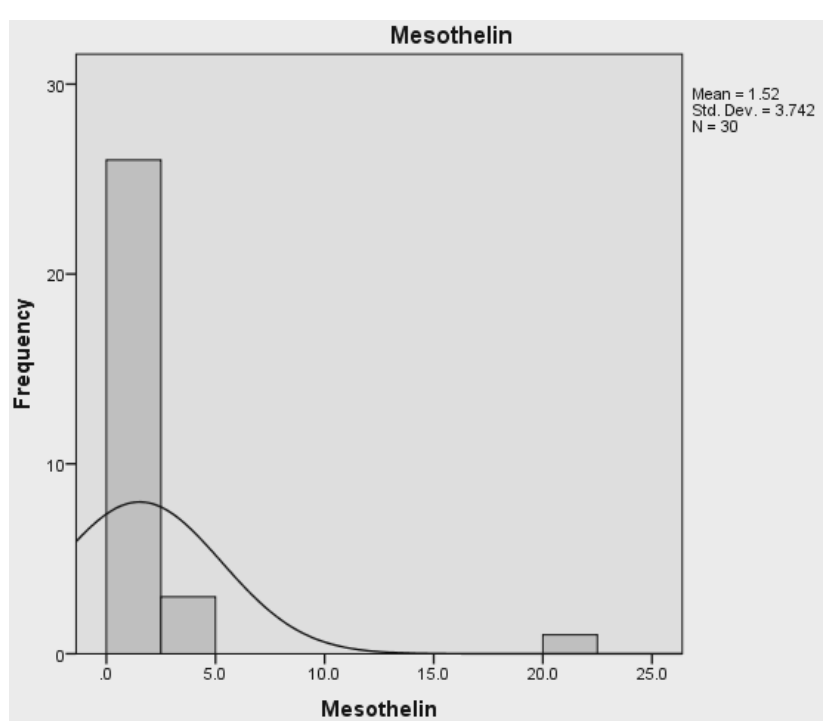

Figure 1. The Graphs of Mesothelin and Ca-125 Level.

meanwhile, if we set up the "cut off point" of mesothelin levels at $0.55 \mathrm{pg} / \mathrm{ml}$, the sensitivity and specificity would be $42.1 \%$ and $72.7 \%$. The interpretation was that $63.2 \%$ sensitivity values obtained from this study was valid if mesothelin levels of $0.45 \mathrm{pg} / \mathrm{ml}$ were used in 100 patients and 63 patients had mesothelin levels greater than or equal to $0.45 \mathrm{pg} / \mathrm{ml}$, they had epithelial ovarian malignant tumor which confirmed through histopa-thology examination as a gold standard. This was implied vice versa for the specificity.

\section{DISCUSSION}

Until 2010, ovarian cancer was still the third malignant diseases in women. According to study conducted by Jemal, et al. in the United States, there were an estimated of 21,880 new cases, whereas 13,850 patients passed away due to this disease. In Indonesia itself, the ovarian cancer was ranked the second after cervical cancer as the cause of gynecological cancer death. Nearly $70 \%$ of women with ovarian cancer were diagnosed in advanced stage so that the five-year survival rate was only $30 \%{ }^{2}$

In this study, the majority of patients were 4059 years old and most of them had three to five children. According to another study, it was found that the population of patients with ovarian tumors were between 20 and 65 years old. This statement

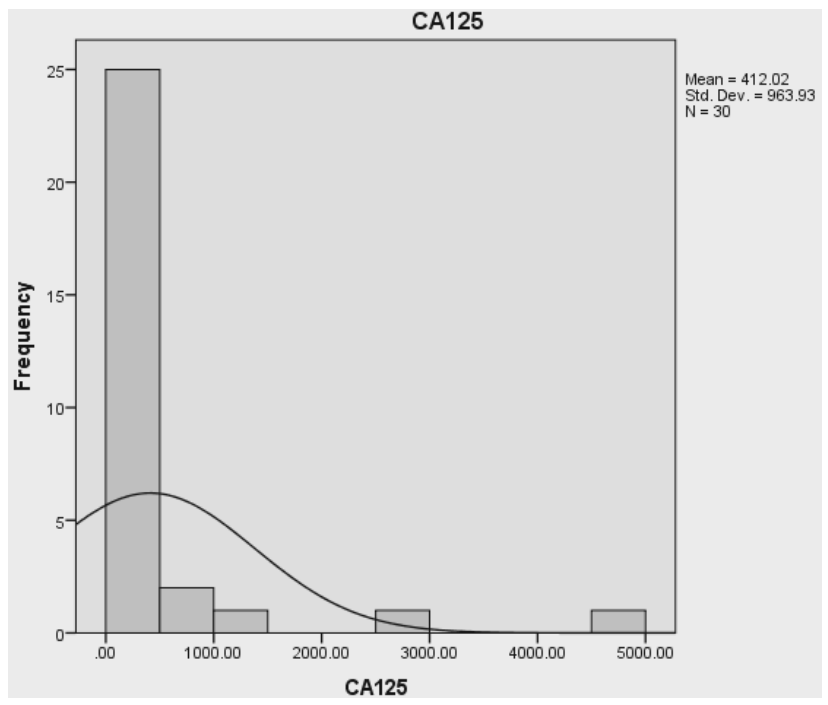

was supported through study by Boy B et al and Diana HF et al where they said that the ovarian malignant tumor was rare under 40 years old. ${ }^{9,10}$ A little bit different result by Martin Siregar, et al, they found that the distribution of patients with ovarian malignant tumor were mostly in the age group of 41 to 50 years old. ${ }^{11}$

Hala Abdel-Azeez, et al in their study reported that the cut-off value for mesothelin was $1.4 \mathrm{nM}$, which meant that it had a lower sensitivity when compared with Ca-125 in detecting ovarian malignancies. Increased mesothelin levels in serum was ranged from $60 \%$ to $77 \%$ in women with ovarian cancer. ${ }^{12}$ Several studies investigated the use of Ca125 and mesothelin as single also combined markers in patients with ovarian malignancy. As a single marker, Ca-125 had higher sensitivity than mesothelin itself. ${ }^{14}$ Although mesothelin could not be used as a single marker to detect ovarian cancer, when combined with Ca-125, it resulted high sensitivity. Serum mesothelin increased at a fraction of patients with normal Ca-125 serum. The combination of Ca-125 and mesothelin would rise the sensitivity compared with a single use of Ca-125 in detecting the ovarian malignancy. According to study by Badgwell, et al. in 2007, mesothelin in the urine acted more sensitive marker than mesothelin serum in the blood to differentiate patients with early-stage of ovarian malignancy. ${ }^{7}$ 


\section{CONCLUSION}

We conclude that mesothelin and Ca-125 are not significantly different to the AUC value of $50 \%$. The optimal sensitivity and specificity for mesothelin was lower than the results shown by Ca- 125 . Therefore, Ca-125 is still used as a tumor marker for screening the ovarian malignancy.

\section{REFERENCES}

1. Chitrathara K. Ovarian cancer comprehensive and contemporary management first ed. Jaypee Brothers Medical Publisher; 2009.

2. Lu KH. Prevention and early detection of endometrial and ovarian cancers in gynecologic cancer ed. Patricia JE, David MG, John JK, Elvio GS. New York: Springer Science; 2006: 15(8).

3. Deligdisch, Liane. Epithelial ovarian cancer in diagnosis and management of ovarian disorders second edition ed. Albert A, Liane D, Nathan K. California: Elsevier Science; 2003: 8494.

4. Hough CD, Sherman-Baust CA, Pizer ES et al. Large scale serial analysis of gene expression reveals genes differentially expressed in ovarian cancer. Cancer Res, 2000; 60: 6281-7.

5. Lowe KA, Shah C, Wallace E et al. Effects of personal characteristics on serum Ca-125, mesothelin, and HE4 levels in healthy postmenopausal women at high-risk for ovarian cancer. Cancer Epidemiol Biomark Preven, 2008; 17(9): 2480-7.
6. McIntosh MW, Drescher C, Karlan B et al. Combining Ca125 and SMR serum markers for diagnosis and early detection of ovarian carcinoma. Gynecol Oncol, 2004; 95(1): 9-15.

7. Bagwell D, Lu Z, Cole L et al. Urinary mesothelin provides greater sensitivity for early stage ovarian cancer than serum mesothelin, urinary hCG free beta subunit and urinary hCG beta core fragment. Gynecol Oncol, 2007; 106(3): 490-7.

8. Jemal A, Bray F, Melissa M et al. Cancer Statictics 2010. CA Cancer J Clin, 2010; 60: 277-300.

9. Busmar V. Tumor ganas ovarium. Dalam: Buku Acuan Nasional Onkologi Ginekologi. Jakarta: Yayasan Bina Pustaka Sarwono Prawirohardjo, 2006: 468-524.

10. Fairley, Diana Hamilton. Carcinoma of the ovary in malignant gynaecological conditions. In: Lecture Notes Obstetrics and Gynaecology Second Ed. Oxford: Blackwell Publishing; 2004: 272-4.

11. Siregar, Martin. Angka kejadian dan karakteristik penderita kanker ginekologi di RSUP H. Adam Malik dan RSUD Dr. Pirngadi, Medan. Bagian Obstetri dan Ginekologi, Fakultas Kedokteran Universitas Sumatera Utara; 2002: 25.

12. Abdel-Azeez1 HA, Labib HA, Sharaf SM et al. HE4 and mesothelin: Novel Biomarkers of ovarian carcinoma in patients with pelvic masses. Asian Pacific J Cancer Prevent, 2010; 11: 111-6. 